\title{
TELEVISION TALK
}




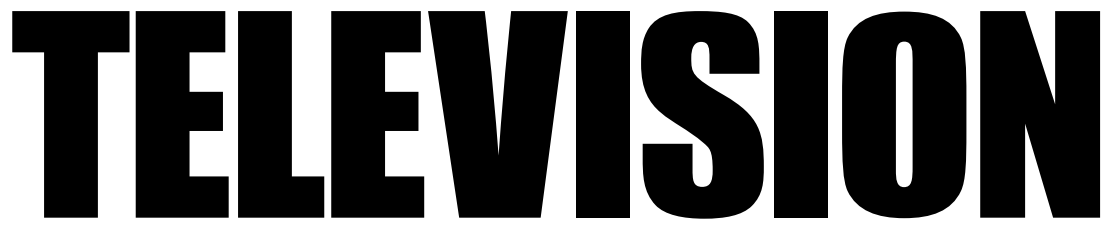


BERNARD M. TIMBERG

with

A Guide to Television Talk by Robert J. Erler

Introduction by

Horace Newcomb 
COPYRIGHT @ 2002 BY THE UNIVERSITY OF TEXAS PRESS

All rights reserved

Printed in the United States of America

Second paperback printing, 2004

Requests for permission to reproduce material from this work should be sent to Permissions, University of Texas Press, P.O. Box 78I9, Austin, TX 78713-78I9.

(0) The paper used in this book meets the minimum requirements of ANSI/NISO Z39.48-I992 (RI997) (Permanence of Paper).

LIBRARY OF CONGRESS CATALOGING-IN-PUBLICATION DATA

Timberg, Bernard.

Television talk : a history of the TV talk show / Bernard M. Timberg with Robert J. Erler.

p. $\quad \mathrm{cm} .-$ (Texas film and media studies series)

Includes bibliographical references and index.

ISBN 0-292-78I76-8 (pbk. : alk. paper)

I. Talk shows-United States. I. Erler, Bob. II. Title. III. Series. PNI992.8.T3 T56 2002

$791.45^{\prime} 6-\mathrm{dc} 21$

2002004368 